\title{
ANALISIS POSTUR KERJA PADA UKM KERAJINAN COR ALUMINIUM
}

\author{
Amarria Dila Sari \\ Jurusan Teknik Industri, Fakultas Teknologi Industri, Universitas Islam Indonesia \\ Jl. Kaliurang Km.14,5 Sleman, Yogyakarta 55584 \\ E-Mail : amarria@uii.ac.id
}

\begin{abstract}
The work process in some aluminum cast aluminum craft shows a series of work that has the risk of injury. UKM Aluminum Correct Handicraft Correct in Bantul, Yogyakarta, untouched in the manufacture of household appliance such as wok as its output. SMEs are divided into several work processes, namely smelting, printing, pengikiran, lathe, brand attachment, and packing. From the results of preliminary observations, the problems encountered in the production process are with potential ergonomic hazard (ergonomic hazard). The posture and work area (less) are less ergonomic as well. The purpose of this study is the prevention of ergonomic hazards, especially with the analysis of work postures that can cause the risk of injury. The results of the work posture category on SME aluminum casting on operators 1 and 2 enter the acceleration category level 3 which requires immediate examination, while operator 3 enters in action level 2 (continued). Terms of repair work system on aluminum cast aluminum that is by changing the work station from work station stands to work station sitting stand at work station finishing and also add chair and table at work of thinking. Also note the stretching and periodic rest.
\end{abstract}

Keywords : Ergonomics, Work Posture, RULA, Aluminum Cor.

\section{PENDAHULUAN}

Industri kecil dan menengah memiliki peran penting dalam perekonomian nasional Indonesia, karena memberikan dampak ganda terhadap perekonomian lokal dan nasional serta membantu dalam menciptakan lapangan kerja. Usaha kecil dan menengah (UKM) adalah kunci untuk perekonomian negara dan sangat penting untuk mencapai tujuan ekonomi nasional (Seneviratne \& Phoon, 2006). Menurut Force (1996) dalam Seneviratne dan Phoon (2006), pada tahun 1997, Small Business Deregulation Task Force di Australia menyatakan bahwa kesehatan dan keselamatan kerja (K3) adalah salah satu permasalahan dan kunci dari ketenagakerjaan UKM.

Industri kecil dan menengah tidak dapat dipisahkan dari berbagai masalah internal dan eksternal. Salah satunya adalah potensi kecelakaan dan kesalahan kerja yang disebabkan oleh faktor manusia, sehingga metode tindakan dan pencegahan benarbenar diperlukan (Arifin, 2013).
Industri pengecoran logam telah lama dianggap sebagai industri berbahaya mengingat interaksi pekerja dengan paparan kedua bahaya yaitu kimia dan fisik (Lei dkk, 2005). Area kerja yang terkontaminasi dengan bahan berbahaya adalah masalah yang perlu diperhatikan bahkan oleh seluruh dunia, perbaikan berdasarkan risiko digunakan untuk menciptakan biaya yang efektif untuk keamanan maksimum bagi pekerjanya di masa depan (Stezar dkk, 2011). Riberio \& Walter Filho (2006) juga menyatakan bahwa industri pengecoran bervariasi dalam hal bahan dan proses, mengakibatkan resiko kerja dari berbagai zat bahaya atau aktivitas kerja yang dapat menyebabkan penyakit, cedera, sakit atau kematian. Concepción - Batiz dkk (2016), menyatakan bahwa pekerja pengecoran memiliki resiko cidera / kesehatan dari beberapa faktor penyebab diantaranya berkaitan dengan Manual Material Handling (MMH), dan postur kerja yang buruk. Hal ini dibuktikan dengan hasil skor analisa postur kerja (REBA) yang menyatakan bahwa 78.9 
$\%$ pekerja berada pada level medium dan high risk.

Proses kerja pada beberapa UKM kerajinan cor aluminium menunjukkan rangkaian kerja yang memiliki resiko cedera, terutama dalam kaitannya terhadap kesehatan dan keselamatan kerja. UKM Kerajinan Cor Aluminium yang berlokasi pada daerah Bantul, Yogyakarta, ini berfokus pada pembuatan alat rumah tangga seperti wajan sebagai output produksinya. UKM ini terbagi menjadi beberapa proses kerja, yaitu peleburan, pencetakan, pengikiran, pembubutan, penempelan merk, dan packing. Dari hasil observasi awal, masalah yang ditemui pada proses produksi adalah berkaitan dengan potensi bahaya ergonomi (ergonomic hazard) diantaranya postur dan area kerja (workstation) yang kurang ergonomis serta beban kerja yang tinggi akan berpengaruh pada bahaya yang dapat menimpa para pekerja.

Studi ini adalah salah satu upaya dalam meminimalkan resiko cedera pada area kerajinan cor aluminium. Tujuan penelitian ini adalah mengidentifikasi ergonomic hazard khususnya berkaitan dengan analisa postur kerja yang dapat menyebabkan resiko cedera dan kecelakaan kerja, serta memberikan rekomendasi untuk mengurangi resiko cedera akibat pekerjaan.

\section{KAJIAN LITERATUR}

\subsection{Ergonomi}

Ergonomi (human factor) merupakan disiplin ilmu yang mempelajari tentang hubungan antara manusia dengan elemen lain dalam sebuah sistem dengan menerapkan teori, prinsip data dan metode dalam proses perancangan dengan tujuan untuk mengoptimalkan kesejahteraan manusia dan performansi kesuluruhan sistem (IEA, 2003). Lebih dari 50 tahun, Ergonomi atau biasa yang disebut dengan Human Factor (HFE), merupakan disiplin keilmuan yang berfokus pada interaksi manusia, dilihat dari perspektif keilmuan engineering, design, technology, management of humancompatible systems, including a variety of natural and artificial products, processes, and living environments (Karwowski, 2006). Beberapa dimensi disiplin ergonomi dapat dilihat pada gambar 1 .

\subsection{Sistem Kerja}

Salah satu bagian dari aplikasi human factor (ergonomi) adalah human error, kecelakaan dan keselamatan kerja (Mc Cormik dan Sanders, 1979). Pendekatan ini menganut prinsip Human Centered Design atau Fit the Job to the Man dimana manusia sebagai pusat sistem. Oleh karena itu semua perancangan sistem kerja diarahkan pada perancangan yang sesuai dengan manusia itu

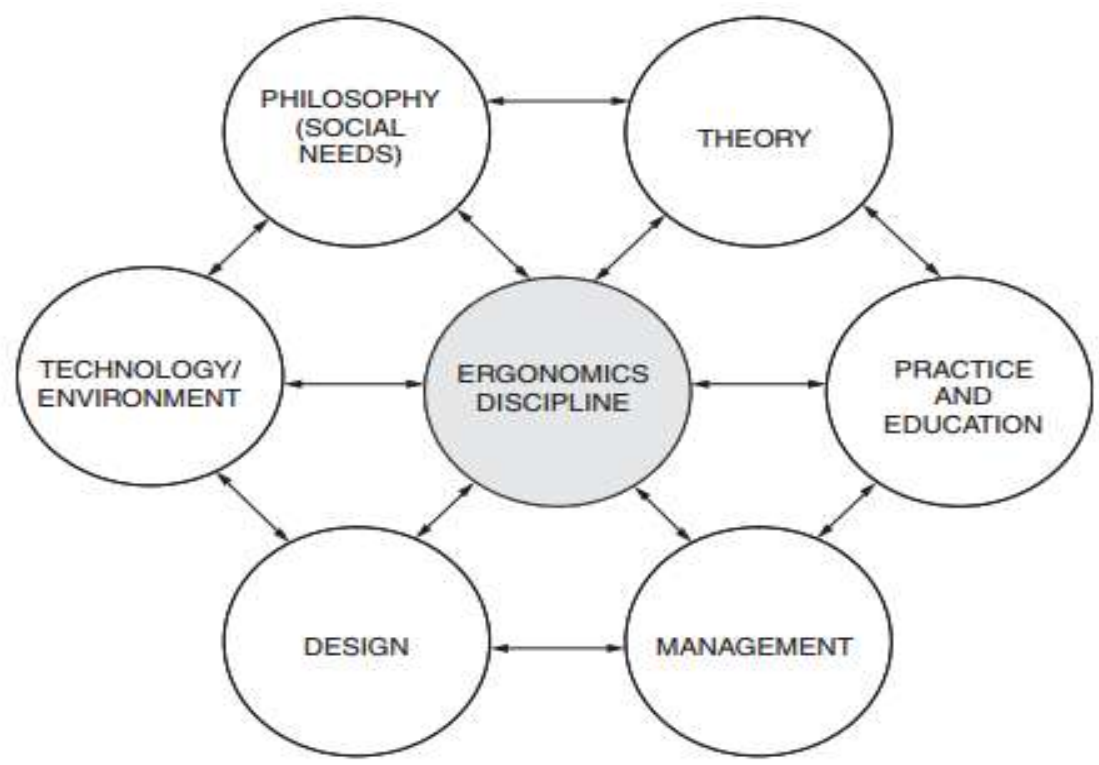

Gambar 1. Dimensi Disiplin Ergonomi. 
Tabel 1. Action Level Metode RULA

\begin{tabular}{c|c|c}
\hline Skor & Action Level & Aksi \\
\hline $1-2$ & 1 & Bisa diterima jika tidak berulang dan periode lama \\
$3-4$ & 2 & Perlu pemeriksaan lanjutan dan perubahan-perubahan \\
$5-6$ & 3 & Pemeriksaan dan perubahan perlu dilakukan segera \\
7 & 4 & Pemeriksaan dan perubahan perlu dilakukan sangat segera \\
\hline
\end{tabular}

sendiri. Menurut Purnomo (2003), tujuan yang hendak dicapai adalah meningkatkan efektivitas kerja yang dihasilkan oleh sistem kerja dengan tetap memandang manusia sebagai pusat sistem untuk mempertahankan dan meningkatkan unsure kenyamanan dan kesehatan. Menurut Kleiner (2006), sistem kerja terdiri dari dua atau lebih orang yang bersama-sama berinteraksi dengan teknologi dalam sistem organisasi yang dicirikan oleh lingkungan internal

\subsection{Keluhan Muskuloskeletal}

Berdasarkan Sanders (2001), keluhan muskuloskeletal merupakan keluhan yang terjadi pada jaringan penghubung (connective tissue) seperti saraf, otot dan joint yang disebabkan karena paparan yang berulang dan berlangsung dalam waktu lama. Keluhan hingga kerusakan pada sendi, ligament dan otot biasanya diisilahkan dengan keluhan Musculoskeletal Disorders (MSDs) atau cidera pada sistem musculoskeletal (Grandjean, 1993).

\subsection{Postur Kerja}

Prinsip sikap tubuh dan postur kerja yang baik secara ergonomis adalah cara kerja yang alamiah dan tidak mengerahkan otot secara berlebihan.
Apabila terdapat gerak, sikap dan posisi kerja yang mengharuskan secara tidak alamiah dan mengerahkan otot secara berlebihan maka sebaiknya tidak melebihi waktu tertentu seperti 2 jam atau tidak berulang secara monoton (Widayana\&Wiratmaja, 2014).

\subsection{RULA}

Metode Rapid Upper Limb Assessment (RULA) merupakan metode penilaian postur tubuh bagian atas (McAtamney dan Corlett ,1993). Input metode ini adalah postur (telapak tangan, lengan atas, lengan bawah, punggung dan leher), beban yang diangkat, tenaga yang dipakai (statis / dinamis), serta jumlah pekerjaan. Metode RULA dapat memberikan analisa yang cepat dalam pekerjaa yang memiliki resiko pada pekerjaan yang berhubungan dengan upper limb disorders, serta mengidentifikasi usaha yang dibutuhkan otot yang berhubungan dengan postur tubuh saat bekerja (penggunaan kekuatan dan kerja statis yang berulang). Input postur metode RULA dibedakan menjadi 2 grup yaitu grup A (lengan atas dan bawah dan pergelangan tangan) dan grup B (leher, tulang belakang dan kaki). McAtamney dan Corlett ,1993 (1993), menetapkan proses metode RULA seperti pada gambar 2 dibawah ini. 


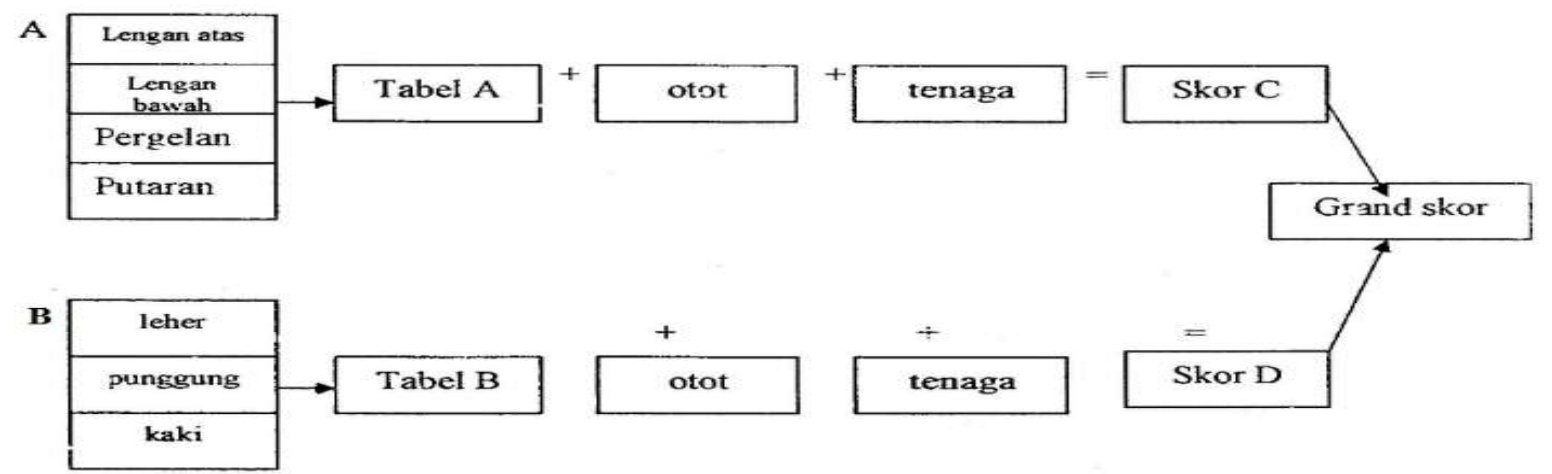

Gambar 2. Metode RULA.

Panduan dalam mengklasifikasikan ditunjukkan dengan tabel sebagai berikut. Tabel 1 diatas.

\section{METODOLOGI PENELITIAN}

Obyek penelitian ini pada UKM pengrajin cor aluminum Wirosaban, Bantul, Jogjakarta.

\subsection{Subyek}

Kriteria sampel yang diterapkan pada penelitian ini adalah sebagai berikut:

Kriteria inklusi :
a. Pekerja UKM Cor Aluminum.
b. Usia 20 - 45 tahun.
c. Pengalaman kerja minimal 1 tahun.
d. Durasi kerja 8 jam / hari.
e. Sehat jasmani rohani.
f. Bersedia menjadi obyek penelitian.

Kriteria Eksklusi (tidak dilanjutkan sebagai sampel)

a. Tidak hadir pada saat penelitian dilaksanakan.

b. Menderita sakit pada saat penelitian.

c. Karena alasan tertentu mengundurkan diri sebagai sampel.

\subsection{Alat dan Bahan Penelitian}

a. Alat dan bahan yang digunakan dalam pengumpulan dan pengolahan data penelitian ini antara lain:

$b$. Alat tulis untuk proses pencatatan data

c. Kuisioner demografi untuk mengetahui karakteristik responden

d. Kamera sony xperia Z5 untuk proses dokumentasi hasil observasi

e. Software ergofellow untuk analisa postur kerja.

\subsection{Prosedur Penelitian}

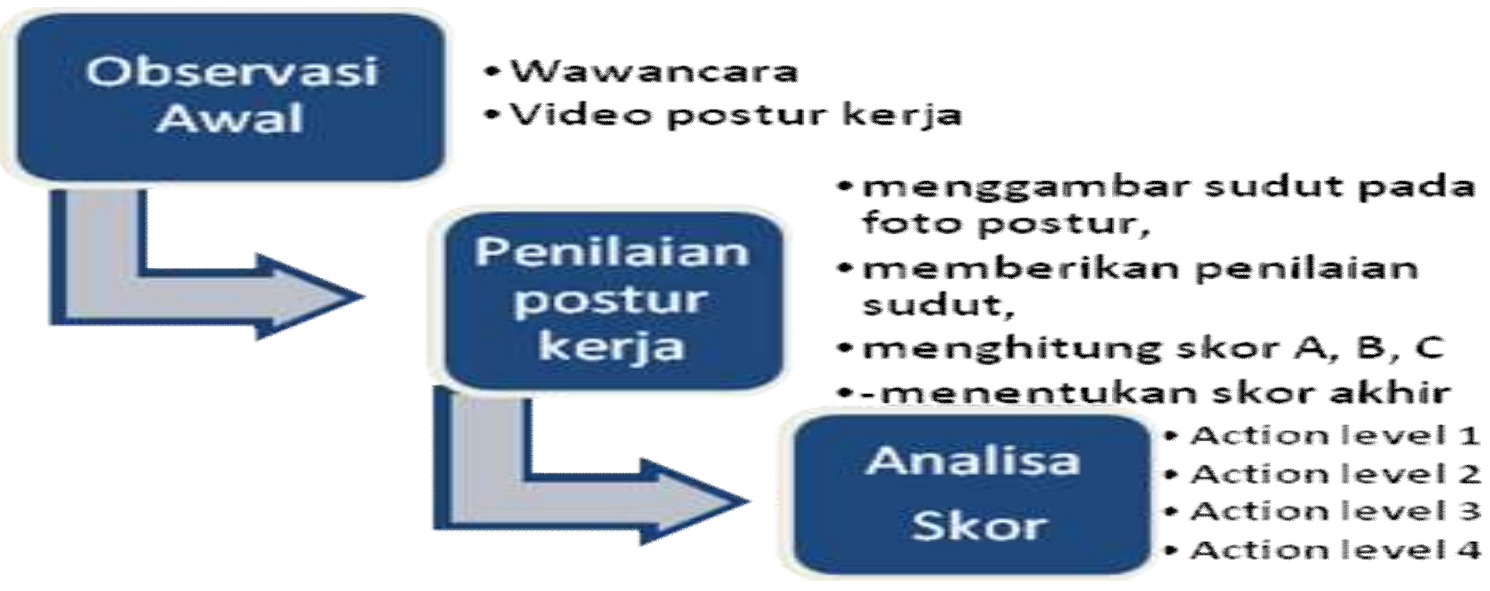

Gambar 3. Prosedur Penelitian. 
4. HASIL DAN PEMBAHASAN

4.1. Karakteristik Responden

Tabel 2. Karakteristik Responden

\begin{tabular}{c|c|c|c|c}
\hline Responden & Jenis Kelamin & Usia & $\begin{array}{c}\text { Durasi } \\
\text { Kerja }\end{array}$ & Unit Kerja \\
\hline Operator 1 & Laki-laki & 27 Tahun & 8 jam & Pengikiran \\
Operator 2 & Laki-laki & 30 Tahun & 8 jam & Pengikiran \\
Operator 3 & Laki-laki & 35 Tahun & 8 jam & Finishing \\
\hline
\end{tabular}

Tabel 2. menunjukan karakteristik dari ketiga responden yang bekerja pada divisi pengikiran dan finishing. Semua responden berjenis kelamin laki-laki dengan durasi kerja 8 jam per hari. Adapun untuk struktur organisasi perusahaan terbagi menjadi 3 divisi meliputi divisi pemasaran, produksi dan Gudang. Divisi Produksi dibagi lagi menjadi 5 bagian/unit kerja yaitu bagian cetak, kikir, bubut, cor dan polis.

\subsection{Analisa Data RULA}

\subsubsection{Operator 1}

Pekerja pada bagian pengikiran, melakukan proses penghalusan tahap awal atau pengkikiran pada produk yang akan dipasarkan. Produk yang dihaluskan adalah produk yang baru selesai diproses pada proses cutting. Pekerja mengkikir untuk merapikan potongan produk, selanjutnya produk disusun pada storage sementara untuk selanjutnya diproses pada divisi finishing untuk penghalusan. Pada kasus UKM ini, pekerja melakukan pekerjaan dengan posisi duduk jongkok dimana alat kikir diletakkan di lantai.(Gambar 4).

Berdasarkan perhitungan yang telah dilakukan, diperoleh score akhir RULA adalah 5 masuk dalam kategori action level 3 , hasil menunjukkan bahwa pemeriksaan dan perubahan perlu segera dilakukan, dalam pekerjaan ini beban $<2 \mathrm{~kg}$ (ringan), sehingga yang perlu diperbaiki adalah posisinya saat bekerja disebabkan karena stasiun kerja yang jongkok dalam waktu lama dapat menyebabkan keram ataupun cidera.

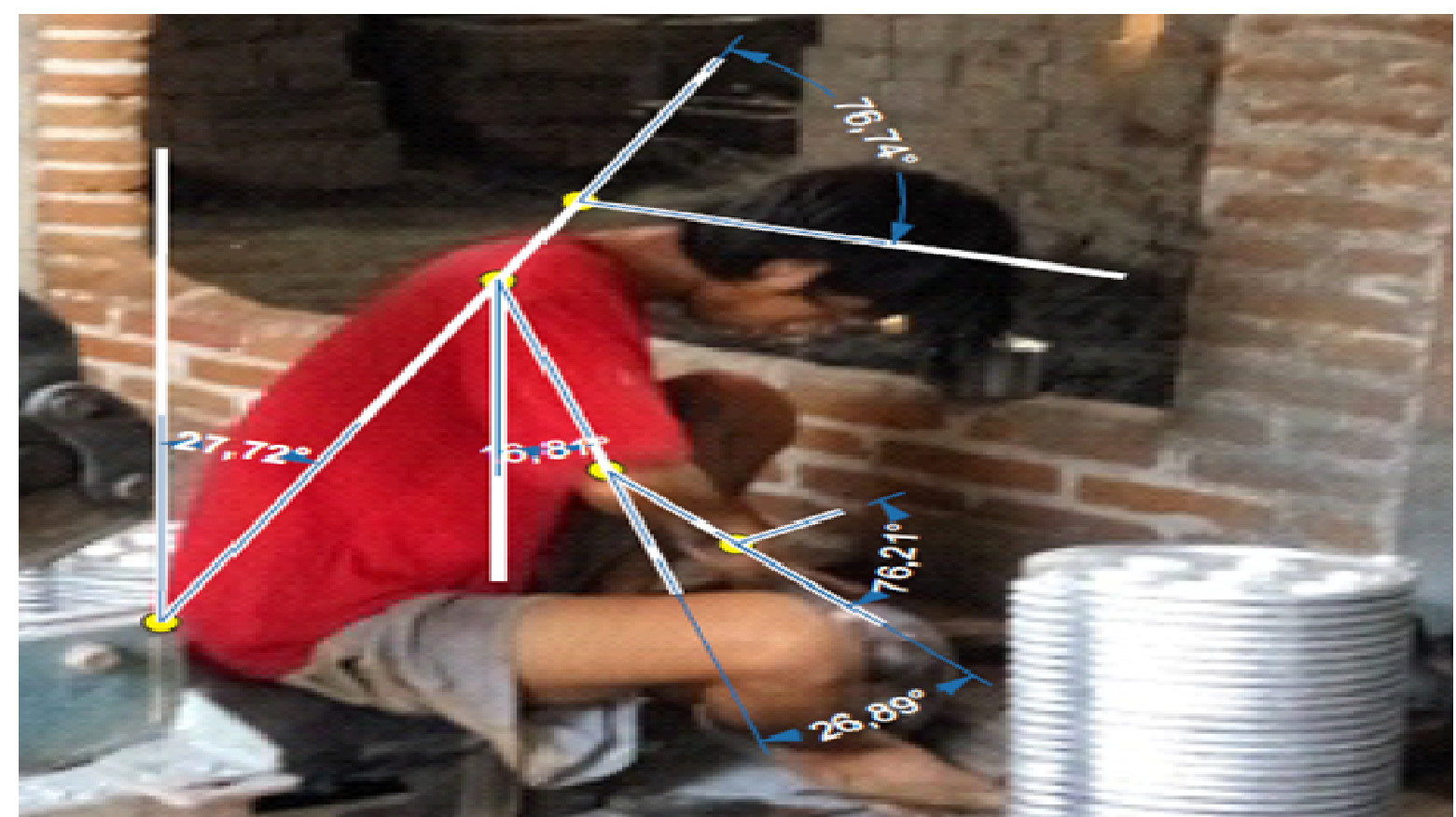

Gambar 4. Postur Kerja Operator 1. 


\subsubsection{Operator 2}

Gambar 5 merupakan pekerja pada bagian pengikiran, pada divisi ini melakukan proses penghalusan tahap awal atau pengkikiran pada produk yang akan dipasarkan. Produk yang dihaluskan adalah produk yang baru selesai diproses pada proses cutting. Pekerja mengkikir untuk merapikan potongan produk, selanjutnya produk disusun di storage sementara untuk selanjutnya diproses pada divisi finishing untuk penghalusan. Pada kasus UKM ini, pekerja melakukan pekerjaan dengan posisi duduk jongkok dimana alat kikir diletakkan dilantai.

Berdasarkan perhitungan yang telah dilakukan, diperoleh score akhir RULA adalah 5 masuk dalam kategori action level 3 , hasil menunjukkan bahwa pemeriksaan dan perubahan perlu segera dilakukan, dalam pekerjaan ini beban $<2 \mathrm{~kg}$ (ringan), sehingga yang perlu diperbaiki adalah posisinya saat bekerja disebabkan karena stasiun kerja yang jongkok dalam waktu lama dapat menyebabkan keram ataupun cidera.

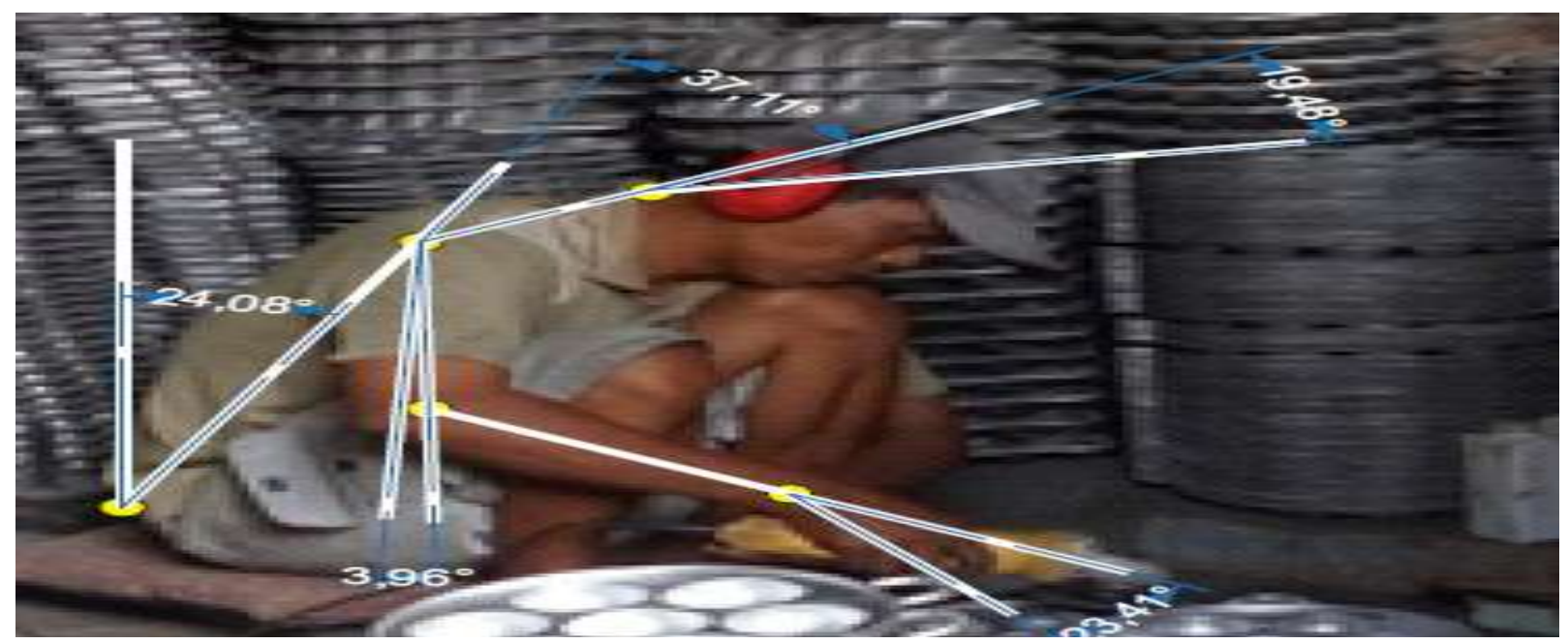

Gambar 5. Postur kerja Operator 2.

\subsubsection{Operator 3}

Gambar 6 merupakan pekerja pada bagian refinning (finishing), produk pada divisi ini akan dihaluskan dengan cara mempolish dan menyikat produk untuk selanjutnya dipasarkan. Beberapa divisi ini

difasilitasi dengan stasiun kerja duduk, ada pula stasiun kerja berdiri. Alat kerja yang digunakan adalah polisher dan penghalus. Produk yang sudah selesai diproses akan disusun di storage untuk dipasarkan.

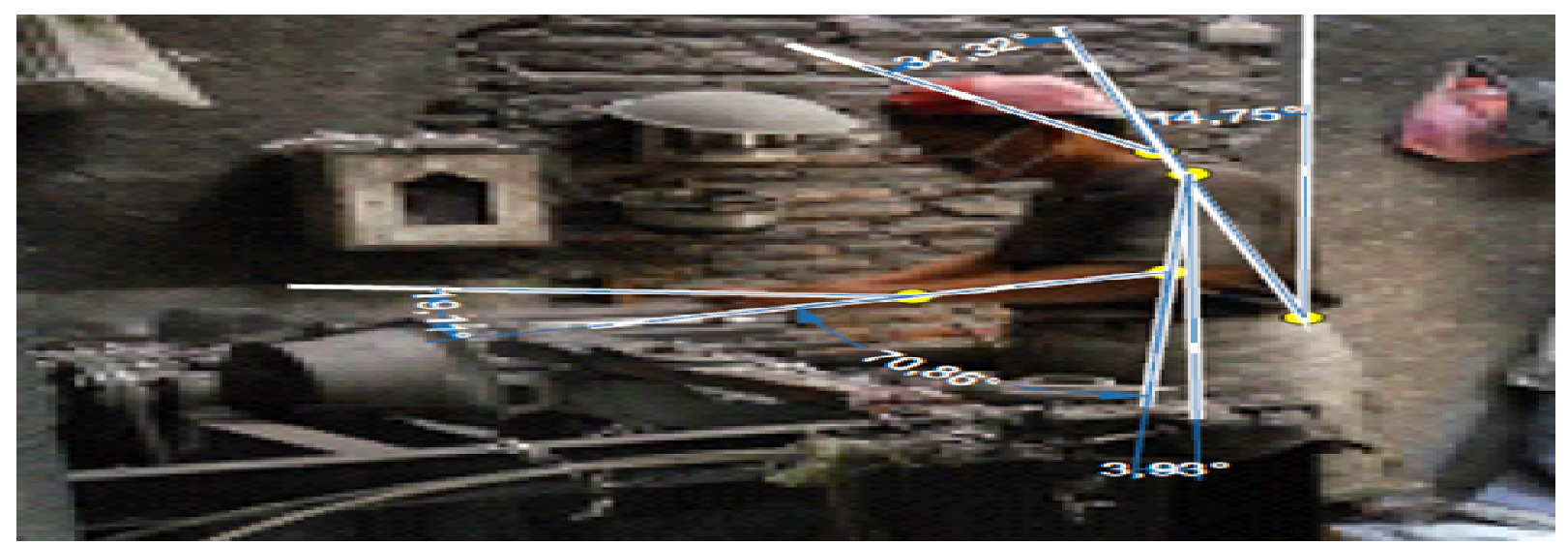

Gambar 6. Postur kerja Operator 3 
Berdasarkan perhitungan yang telah dilakukan, diperoleh score akhir RULA adalah 4 masuk dalam kategori action level 2 , hasil menunjukkan bahwa pemeriksaan dan perubahan perlu segera dilakukan, dalam pekerjaan ini beban $<2 \mathrm{~kg}$ (ringan), sehingga yang perlu diperbaiki adalah posisinya saat bekerja disebabkan karena stasiun kerja yang jongkok dalam waktu lama dapat menyebabkan kram atau cidera.

\subsubsection{Rekomendasi Perbaikan Kerja}

Berdasarkan dari hasil analisis postur kerja menggunakan metode RULA diperoleh rekomendasi perbaikan sikap kerja yang dapat diberikan adalah sebagai berikut :

1. Sikap kerja operator pada fase kegiatan pengikiran yang masih beresiko gangguan muskuloskeletal disebabkan oleh sikap jongkok di lantai dengan lutut ditekuk. Usulan perbaikan yang dapat diberikan adalah perubahan postur kerja dengan menggunakan kursi dan meja tambahan agar tidak terjadi kram / cidera.

2. Sikap kerja operator pada fase kegiatan finishing yang dapat menyebabkan cidera karena posisi berdiri dengan membawa beban dan dengan durasi yang lama, maka direkomedasikan untuk merelayout stasiun kerja duduk berdiri.

3. Melakukan pelatihan kepada pekerja untuk memberikan pengetahuan tentang postur kerja dan manual handling yang baik dan tepat serta menjelaskan akibat yang ditimbulkan bila tidak dilakukan secara baik dan tepat. Penjelasan ini bisa melalui pelatihan lisan maupun dengan menempelkan poster di tempat yang mudah dilihat.

4. Melakukan stretching atau pemanasan sekitar 10 - 15 menit sebelum bekerja untuk menghindari kontraksi otot secara tiba - tiba dan kontraksi berlebihan (Utomo, 2012).

\section{KESIMPULAN}

a. Hasil kategori penilaian postur kerja pada UKM cor aluminium pada operator 1 dan 2 masuk dalam kategori action level 3 dimana perlu pemeriksaaan segera, sedangkan operator 3 masuk dalam action level 2 (perlu pemeriksaan lanjutan).

b. Rekomendasi perbaikan sistem kerja pada UKM cor aluminium yaitu dengan merubah stasiun kerja dari stasiun kerja berdiri menjadi stasiun kerja duduk berdiri pada stasiun kerja finishing serta menambahkan kursi dan meja pada pekerjaan pengikiran. Selain itu perlu adanya stretching dan istirahat berkala.

\section{DAFTAR PUSTAKA}

Arifin, M. 2013. Perancangan Tata Letak Pada Unit Pengecoran Logam Dengan Sinkronisasi Lintasan Kerja Untuk Meminimalisasi Hazard Di Ed Alloycasting Production C-Maxi (Doctoral Dissertation, Uin Sunan Kalijaga).

Concepción-Batiz, E., dos Santos, A. J., Berretta-Hurtado, A. L., Macedo, M., \& Schmitz-Mafra, E. T. 2016. Assessment of postures and manual handling of loads at Southern Brazilian Foundries/Evaluación de las posturas y la manipulación de cargas manuales en fundiciones del sur de Brasil. Revista Facultad de Ingenieria Universidad de Antioquia, (78), 21.

Force, S. B. D. T. 1996. Time for Business: Report of the Small Business Deregulation Task Force. Canberra : Commonwealth of Australia.

IEA. 2003. IEA Triennial Report, 2000 2003, IEA Press, Santa Monica, CA.

Karwowski, W. 2006. The discipline of ergonomics and human factors. Handbook of human factors and ergonomics, 3 . 
Kleiner, B. M. 2006. Macroergonomics: analysis and design of work systems. Applied ergonomics, 37(1), 81-89.

Lei, L., Dempsey, P. G., Xu, J. G., Ge, L. N., \& Liang, Y. X. 2005. Risk factors for the prevalence of musculoskeletal disorders among Chinese foundry workers. International Journal of Industrial Ergonomics, 35(3), 197-204.

McAtamney, L., \& Corlett, E. N. (1993). RULA : a survey method for the investigation of work-related upper limb disorders. Applied ergonomics, 24(2), 91-99.

Purnomo, H. 2003. Pengantar Teknik Industri. Yogyakarta : Graha Ilmu.

Ribeiro, M. G., \& Walter Filho, R. P. 2006. Risk assessment of chemicals in foundries: The International Chemical Toolkit pilot-project. Journal of hazardous materials, 136(3), 432-437.

Sanders, M. S., \& McCormick, E. J. 1987. Human factors in engineering and design. McGRAW-HILL book company.

Seneviratne, M., \& Phoon, W. O. 2006. Exposure assessment in SMEs: a low-cost approach to bring OHS services to small - scale enterprises. Industrial Health, 44(1), 27-30.

Sharma, R., \& Singh, R. 2014. Work Related Musculoskeletal Disorders, Job Stressors and Gender Responses in Foundry Industry. International Journal of Occupational Safety and Ergonomics, 20(2), 363-373.
Stezar, I. C., Modoi, O. C., Török, Z., Ajtai, N., Crişan, A. D., Coşara, G. V., \& Ozunu, A. 2011. Preliminary Investigation And Risk Assessment Of Contamination On An Industrial Site In Maramures County. Environmental Engineering \& Management Journal (EEMJ), 10(1).

Utomo, A.2012. Gambaran Tingkat Risiko Ergonomi dan Keluhan Gangguan Trauma Kumulatif pada Pekerja Pabrik Rahmat Tempe di Pancoran Jakarta Selatan. Universitas Indonesia, Depok.

Wanave, Sandip B., Bhadke, Manish, K. 2014. An Ergonomics Intervention in a Transformer Manufacturing Industry to Improve the Productivity. IOSR Journal of Mechanical and Civil Engineering (IOSR-JMCE). PP 52-57.

Widayana, I, G., Wiratmaja, I, G. 2014. Kesehatan dan Keselamatan Kerja. Edisi Pertama. Graha Ilmu. Yogyakarta. 